\title{
New scientific school in the space of Moscow Municipal Pedagogical University
}

\author{
Nikolay Mikhaylov, Elvira Mikhaylova, Elena Derevleva* \\ Moscow Municipal Pedagogical University, 129226, Moscow, Russia
}

\begin{abstract}
The article presents achievements of the forming scientific school "Theory and methodology of aerobics". It systematizes the experience of aerobics for scientific-pedagogical staff training in the system of education in Moscow. Scientific school under the direction of professor E.I. Mikhaylova systematized own achievements for the $25^{\text {th }}$ anniversary of Moscow Municipal Pedagogical University. The article actualizes the indices of the scientific school in developing scientific and educational-methodical support of aerobics lessons at different stages of education, systematizes success in training athletes. They represent the Russian Federation at the International level. The article presents the examples of training teachers for educational establishments of Moscow.
\end{abstract}

\section{Introduction}

It is known that any educational establishment of higher education is proud of the existing scientific schools achievements. They accumulate, systematize and introduce scientific achievements during modern national economy specialists training [1, c. 6; 4].

Recently in Moscow Municipal Pedagogical University (further University) significant changes happen. They are directed at the Strategy realization of Moscow Municipal Pedagogical University development till 2025. Pedagogical Institute of Physical culture and Sport was transformed since July, 1, 2018 into Natural Science and Sports Technologies Institute (NSSTI). It led to the range of structural changes, for example "Theory and methodology of physical upbringing and sports training" department was transformed into "Physical upbringing and life safety" department; "Theory and methodology of sports disciplines" department turned into "Adaptology and sports disciplines department". By 2018 two scientific schools were formed and functioned at NSSTI. They systematized the experience in the sphere of physical culture and sport. The first scientific school "Theory and methodology of youth sport" was created and is directed by professor Viktor Grigorevich Nikitushkin. The second school "Theory and methodology of motor activity organization and the process of exercises organization in the structure of sports training and physical upbringing practice" was closed because its director professor Gennadiy Nikolaevich Germanov left NSSTI. However, nowadays in 2020 , when we celebrate the $25^{\text {th }}$ anniversary of the University, there appeared a new school "Theory and methodology of aerobics" (further-Scientific school). This school formation is realized under the direction of professor Elvira Ivanovna Mikhaylova. She is the head of the school during the period since 2010 till 2020. Under her direction aerobics is systematized, introduced and developed in the system of Russian education on the basis of the University. In this article we would consider future development of the presented scientific school, both in health-improving aerobics development and its role in health improvement in different age groups [5-8] and in sports training development for competitions during aerobics lessons $[2,3]$.

\section{Statement of problem}

In terms of the present research work we used aerobics means and methods analysis, systematization and introduction for training the future specialists in physical culture and sport for the system of education in Moscow. We summarized the results of training sports reserve and the national aerobics team of Russia, the results of scientific research works concerning the problems of health-improving and sports aerobics study in the Russian Federation and in Moscow region. The materials of the research formed the base for the scientific school content substantiation ("Theory and methodology of aerobics"). The research works were held during the period since 2010 till 2020 on the basis of Moscow Municipal Pedagogical University.

\footnotetext{
${ }^{*}$ Corresponding author: ederevleva@yandex.ru
} 


\section{Results and Discussion}

In the opinion of the scientists, the scientific school is characterized by the following features [1, p. 6-7]:

- community of the school representatives scientific interests and scientific significance of the considered problems;

- the level of school scientific results and its acknowledgement in the country and abroad;

- the role of the scientific leader;

- continuity of scientific generation, work with scientific youth.

The stress in the work of Scientific school during recent years was on knowledge systematization. It is necessary for controlling the processes of health improving aerobics use at educational establishments for a healthy life style formation among the oncoming generation and knowledge of aerobics use for sports training process organization among sports reserve and taking part in competitions among the students of the University.

During Scientific school formation the authors used the definition, that it presents the unity of research workers. It realizes the function of new knowledge production and provides self-reproduction [4].

Scientific school under the direction of professor E.I. Mikhaylova studies aerobics, as the kind of a person's motor activity.

Professor E.I. Mikhaylova has been studying the problems of aerobics more than 40 years, promoting aerobics lessons as a kind of motor activity for the population into the system of native physical upbringing since the end of the XX century. Today she organizes the process of professional competencies formation in students of the University. These competencies are necessary for aerobics lessons organization with different groups of population, preferring educational establishments of Moscow. Her authority in this sphere is proved by practical experience as vice-president of the USSR Sports aerobics Federation and then later of Russia, a long-term practice of teaching at higher educational establishments.

An important result of Scientific school activity became educational-methodical manuals and aerobics textbook preparation and publishing. Since 2014 the authors of this publication regularly prepared and published educationalmethodical manuals for physical culture and sport specialists and students of the University. They were published in "Soviet sport", Yurayt publishing house and in scientific- editorial publishing center of the University.

In 2015 the scientific- editorial publishing center of the University prepared and published the textbook for physical culture and sport institutes "Aerobics". Thus, the base of scientific-methodical materials was formed. They could be used by students, who studied at the specialty 49.03.01 Physical culture and 43.03.01 Pedagogical education.

Also the programs of qualification improvement for the specialists of educational system in Moscow, presented in table 1, were paid attention to. For physical culture teachers the representatives of Scientific school created and organized the courses of qualification improvement "Aerobics for health improvement among children and young people". It has been mustered by several streams of school teachers of Moscow since 2012.

Table 1. The content of the events connected with qualification improvement held by scientific school "Theory and methodology of aerobics"

\begin{tabular}{|c|c|c|c|}
\hline № & $\begin{array}{l}\begin{array}{l}\text { Description } \\
\text { improvement }\end{array} \\
\end{array}$ & Client & Number of participants \\
\hline 1 & $\begin{array}{l}\text { Beauty in movement- health since } \\
\text { childhood (2011) }\end{array}$ & $\begin{array}{l}\text { Federal Center of } \\
\text { Organizational-Methodical } \\
\text { Support of Physical Upbringing } \\
\text { of Moscow City Department of } \\
\text { Education together with Health- } \\
\text { improving educational centers of } \\
\text { regional education departments } \\
\text { for children in Moscow }\end{array}$ & 41 \\
\hline 2 & $\begin{array}{l}\text { Master class "Fitness-aerobics at } \\
\text { physical culture lessons" (2016) }\end{array}$ & $\begin{array}{l}\text { Moscow Municipal Pedagogical } \\
\text { University in terms of scientific- } \\
\text { practical conference } \\
\text { "Innovations in physical } \\
\text { upbringing and sports training" }\end{array}$ & 23 \\
\hline 3 & $\begin{array}{l}\text { Seminars for kindergarteners and } \\
\text { judges in training for physical } \\
\text { culture Olympiad for pre-school } \\
\text { children "Young Olympians" } \\
(2016-2018)\end{array}$ & $\begin{array}{l}\text { Center of physical upbringing of } \\
\text { Moscow "Vorobevy gory" State } \\
\text { budgetary professional } \\
\text { educational establishment }\end{array}$ & 149 \\
\hline 4 & $\begin{array}{l}\text { "Fitness-technologies at physical } \\
\text { culture lessons" (2020) }\end{array}$ & $\begin{array}{l}\text { International school for gifted } \\
\text { children "Letovo", } \\
\text { Moscow. }\end{array}$ & 11 \\
\hline
\end{tabular}


E.I. Mikhaylova is a constant participant of educational seminars for judges and fitness-aerobics coaches on the basis of Sports aerobics and fitness-aerobics Federation in Moscow city since 2000.

None of scientific schools can exist without scientific research works organization in the offered sphere of activity. Under the direction of professor E.I. Mikhaylova two dissertations of candidate of pedagogics were prepared and defended:

$>$ Derevleva E.B. Professional training of pedagogical higher educational establishment students for aerobics teaching at schools. Moscow: Moscow Municipal Pedagogical University, 2009.

$>\quad$ Khayrullina A.A. School teams training for aerobics competitions. Moscow: Moscow Municipal Pedagogical University, 2012.

Continuity in work of Scientific school was not created at once, but since 2010 research advisors, who work at the University, professor E.I. Mikhaylova, associate professor Derevleva and associate professor N.G. Mikhaylov realized the control over graduate qualification works of the specialists and later bachelors and undergraduates of the University. As the example we can mention master's thesis of World-class athlete, Sports aerobics World champion, Universiade 2019 champion in Krasnoyarsk, Denis Solovev: Basic physical training of highly-qualified aerobics athletes, in which the author analyzed the experience of sports training in sports aerobics. The questions of bringing up physical qualities are presented in graduate qualification work by Darya Nazarova: Methodology of sports aerobics lessons organization with senior pre-school children, by Ekaterina Ratnikova- Methodology of speed-power oriented abilities development in the group of fitness-aerobics initial training; master's thesis of Aleksei Logunov - Methodology of power oriented training among men of the first adulthood at the lessons in fitness-club.

The research works are carried out. They analyze competitive activity according to the separate directions of sports aerobics. The example of this direction graduate qualification work can be the work of Mariya Kulchitskaya: "Methodology of competitive exercises creation in sports aerobics for 12-14 year-old children" and also more than 20 graduate qualification works and 15 master's theses. They discuss different aspects of health-improving and sports aerobics lessons.

The results of the Scientific school activity at the University became the training of 43 specialists. They teach aerobics of physical upbringing process at schools of Moscow and involve children and young people into sports and health-improving aerobics lessons in the system of sports orientation additional education.

The second direction of Scientific school was oriented at modern means and methods of sports training creation and introduction among highly-qualified athletes. Here aerobics takes the estimable place in achievements of Moscow Municipal Pedagogical University (MMPU) (table 2).

Table 2.Achievements in sports training of scientific school "Theory and methodology of aerobics"

\begin{tabular}{|c|c|c|c|}
\hline Year & $\begin{array}{l}\text { Results of MMPU team } \\
\text { in MSSG Moscow } \\
\text { Students Sports Games } \\
\text { (MSSG) }\end{array}$ & $\begin{array}{l}\text { Results of } \text { MMPU } \\
\text { students in Russia } \\
\text { Championships and Cups }\end{array}$ & $\begin{array}{lrr}\text { Results of } & \text { MMPU } \\
\text { students at } & \text { World } \\
\text { Championship } & \text { and } \\
\text { International tournaments }\end{array}$ \\
\hline 2010 & 1 place $\mathrm{SA}^{* *}$ & & \\
\hline 2011 & 1 place $\mathrm{SA}$ & & \\
\hline 2012 & 1 place $\mathrm{SA}$ & & \\
\hline 2013 & 1 place $\mathrm{SA}$ & & \\
\hline 2014 & $\begin{array}{l}1 \text { place } S A \text {, } \\
\text { FA prizewinners } * * \text { : hip- } \\
\text { hop }\end{array}$ & $\begin{array}{lll}\text { Chudakova } & \text { Anna } & -1 \\
\text { place FA; } & & \\
\text { MMPU team FA } \\
\text { prizewinners: hip-hop }\end{array}$ & \\
\hline 2015 & $\begin{array}{l}1 \text { place } \begin{array}{c}\text { SA, } \\
\text { prizewinners: hip-hop }\end{array} \\
\end{array}$ & $\begin{array}{l}\text { Chudakova Anna }-1 \\
\text { place FA; } \\
\text { MMPU team FA } \\
\text { prizewinners: hip-hop }\end{array}$ & \\
\hline 2016 & $\begin{array}{l}1 \text { place } \begin{array}{c}\text { SA, } \\
\text { prizewinners: hip-hop }\end{array} \\
\text { FA }\end{array}$ & $\begin{array}{l}\text { Chudakova Anna }-1 \\
\text { place FA; } \\
\text { MMPU team FA } \\
\text { prizewinners: hip-hop }\end{array}$ & \\
\hline 2017 & 1 place $S A$ & $\begin{array}{l}\text { Chudakova } \\
\text { place FA; }\end{array}$ & \\
\hline 2018 & 1 place $S A$ & $\begin{array}{l}\text { Chudakova } \\
\text { place FA; }\end{array}$ & \\
\hline 2019 & $\begin{array}{l}1 \text { place } S A, \\
3^{\text {rd }} \text { place, FA, hip-hop }\end{array}$ & $\begin{array}{l}\text { Russia Championship } \\
\text { Dzhanazyan Garsevan - } \\
\left(\text { TR* } 2^{\text {nd }} \text { place GR } 2^{\text {nd }}\right. \\
\text { place AD } 3^{\text {rd }} \text { place); } \\
\text { Dzhanazyan Dukhik }- \\
\left(\text { TR* } 2^{\text {nd }} \text { place GR } 2^{\text {nd }}\right.\end{array}$ & $\begin{array}{l}\text { Dzhanazyan Garsevan, } \\
\text { Dukhik } \\
\text { European championship } \\
\left(\mathrm{GR}-\text { the } 2^{\text {nd }} \text { place, AD }\right. \\
- \text { the } 2^{\text {nd }} \text { place, team }-1^{\text {st }} \\
\text { place) European Olympic }\end{array}$ \\
\hline
\end{tabular}




\begin{tabular}{|l|l|l|}
\hline & place). & Games; GR $1^{\text {st }}$ place. \\
& Russia Cup: & \\
Dzhanazyan Garsevan, & \\
Belousov Aleksei $-1^{\text {st }}$ & \\
place in the group. & \\
\hline
\end{tabular}

*Notes: TR - trio, GR - group, AD -aerodance; **SA - sports aerobics, FA- fitness-aerobics.

MMPU team in sports aerobics is eight times champion and multiple prizewinner of Moscow students sports games in sports aerobics. Chudakova Anna, threefold World champion studies at Natural Science and Sports Technologies Institute. She is master of the $2^{\text {nd }}$ course, this year she finishes studies according to "Integral approach in training high category athletes" program. In 2020 the graduates of the University are: the World champion and the winner of Universiade 2019 Dzhanazyan Garsevan, World-class athlete; Shurupov Denis - Europe champion, World-class athlete, and also several athletes, who are masters of sports of the Russian Federation: Chernousova Darya, Belousov Aleksei, masters of the $2^{\text {nd }}$ course of Adaptology and sports training department. These students combine education and scientific activity, study the problems of training athletes in this kind of sport and continue the traditions of aerobics native school.

In 2019 master's degree received the World champion in several nominations of competitions in aerobics, the winner of the Universiade in Krasnoyarsk, Solovev Denis, Merited Master of Sports; and Dzhanazyan Dukhik, World champion in group competitions, Merited master of sports.

High class athletes' results are the example for the students of the University and they involve them into aerobics. Boys and girls, bachelors and masters constantly enter national team of the University, take part in sports events and students evenings. Traditionally since 2013 University team of students (50 people) takes part in Moscow International festival FIT-EXPO, demonstrating hip-hop aerobics programs. University aerobics group constantly participates in demonstration performances at different city and sports events.

\section{Conclusions}

During the period since 2010 till 2020 scientific school "Theory and methodology of aerobics" is formed at Natural Science and Sports Technologies Institute. It is characterized by the following features:

$\checkmark \quad$ combines the group of specialists under the direction of professor E.I. Mikhaylova;

$\checkmark$ carries out scientific research works at all stages of training specialists in aerobics from bachelors to undergraduates;

$\checkmark \quad$ every year trains specialists in health-improving and sport aerobics for the work at educational establishments of Moscow and Moscow region, additional education establishments of these regions;

$\checkmark \quad$ introduces modern means and methods of sports aerobics into the training process of highly-qualified athletes, which help to win at high rank competitions.

The authors express their sincere appreciation to: Vladislav Oskner, president of Russian Social Organization "Sports aerobics federation in Moscow", Kalinkina Kira Viktorovna, physical culture teacher of secondary school № 538, Moscow, Khayrullina Alsou Alievna, high category kindergartener of autonomous educational establishment preschool № 2 "Zolotaya Rybka", Dolgoprudnyi, Russia.

\section{References}

1. O.Yu. Grezneva Scientific schools (Moscow, 2003).

2. E.I. Mikhaylova, N.G. Mikhaylov, All-Russian scientific-practical conference "Future development of modern students sport. Results of performances of Russian athletes at Universiade -2013 in Kazan (Kazan, December, 12-13, 2013), (Kazan, 2014)

3. E.I. Mikhaylova, N.G. Mikhaylov, E.B. Derevleva, Pedagogico-psychological and medico-biological problems of physical culture and sport. 12(3), 173-178, (2017)

4. E.V. Ustyuzhanina, S.G. Evsyukov, A.G. Petrov, R.V. Kazankin, M.B. Dmitrieva, Scientific school as a structural unit of scientific activity, (Central Economic-Mathematical Institute of Russian Academy of Sciences, Moscow, 2011)

5. R.H. Cox, M.P. Martens, W.D. Russel, Journal of Sport and Exercise Psychology, 25, 519-533, (2003).

6. L.L. Craft, M. Magyar, B.J. Becker, D.L. Feltz, Journal of Sport and Exercise Psychology, 25, 44-65, (2003).

7. O.N. Stepanova, S.V. Savin, Russian Journal of Physical Education and Sport, 15(1), 80-83, (2020).

8. K. Walseth, I. Aartun, G. Engelsrud, Journal Sport, Education and Society, 22(4), 442-459, (2017). 